\title{
MEMBANGUN MODEL KOMUNIKASI PROGRAM TANGGUNGJAWAB SOSIAL PERUSAHAAN UNTUK KEBERDAYAAN MASYARAKAT SEKITAR (Studi Kasus Desa Lulut, Kabupaten Bogor)
}

\author{
${ }^{1}$ David Rizar Nugroho, ${ }^{2}$ Aida Vitayala S. Hubeis, \\ ${ }^{3}$ Amiruddin Saleh, dan ${ }^{4}$ Wahyu Budi Priatna \\ ${ }^{1}$ Dosen Fakultas Ilmu Komunikasi Universitas Pakuan \\ ${ }^{2}$ Guru Besar Sains Komunikasi dan Pengembangan Masyarakat Institut Pertanian Bogor \\ ${ }^{3}$ Dosen Sains Komunikasi dan Pengembangan Masyarakat Institut Pertanian Bogor \\ ${ }^{4}$ Dosen Agribisnis Institut Pertanian Bogor \\ E-mail: jubirdavid@gmail.com
}

\begin{abstract}
ABSTRAK. Program Tanggung Jawab Sosial (TJS) perusahaan menjadi salah satu ukuran kepedulian perusahaan terhadap masyarakat sekitar perusahaan yang selanjutnya menjadi aspek penting dalam keberdayaan masyarakat. Tujuan penelitian secara khusus adalah (1) Mengetahui persepsi penerapan saluran komunikasi dan pendekatan komunikasi yang dilakukan dalam program TJS perusahaan. (2) Mengetahui faktor-faktor yang membentuk karakteristik penerima manfaat. (3) Menganalisis pengaruh karakteristik penerima manfaat, saluran komunikasi dan pendekatan komunikasi program TJS perusahaan terhadap keberdayaan masyarakat. Lokasi penelitian adalah Desa lulut, Kabupaten Bogor dengan ukuran sampel yang digunakan dalam penelitian ini sebanyak 74 responden. Penelitian ini didesain menggunakan metode campuran (mix method) dengan menggunakan analisis deskriptif dan structural equation model (SEM). Hasil dari penelitian ini meliputi : (1) Persepsi responden terhadap peubah saluran komunikasi secara umum dinilai baik, sedangkan untuk pendekatan komunikasi dan keberdayaan masyarakat secara umum dinilai buruk. (2) faktor - faktor yang membentuk kareakteristik penerima manfaat adalah pendidikan dan status sosial. (3) Peubah yang mempengaruhi keberdayaan masyarakat adalah pendekatan komunikasi dan saluran komunikasi, sedangkan karakteristik penerima manfaat berpengaruh terhadap saluran komunikasi.
\end{abstract}

Kata kunci: model komunikasi, tanggung jawab sosial perusahaan, pemberdayaan masyarakat

\section{BUILDING A MODEL OF COMMUNICATION PROGRAM CORPORATE SOCIAL RESPONSIBILITY FOR COMMUNITY DEVELOPMENT (Case Study Lulut Village, District Bogor)}

\begin{abstract}
Program Corporate Social Responsibility (TJS) into one measure of the company's concern about public companies that subsequently an important aspect of community empowerment. The research objective in particular is (1) Determine the perceptions of the application of communication channels and approaches to communications made in the program TJS companies. (2) Determine the factors that shape the characteristics of the beneficiaries. (3) to analyze of the characteristics of the beneficiaries, and the influence of communication channel approach program TJS the company towards community empowerment. The research location is lulut village, Bogor regency. The samples size used in this study were 74 respondents. This study is designed as a quantitative research boosted by the mix methode approach using descriptive analysis and structural equation modeling (SEM). The results of this study include: (1) Perceptions of respondents to variables of communication channels is generally considered good, while for communication and community empowerment approach is generally considered bad. (2) education and social status are factors that make up characteristics of beneficiaries. (3) The variables that affect the community empowerment approach is communication and communication channels, while the characteristics of the beneficiary effect on the communication channels.
\end{abstract}

Key words: Communications model, corporate sosial responsibilty, community empowerment

\section{PENDAHULUAN}

Perusahaan merupakan bagian dari masyarakat dan lingkungan, keberadaan perusahaan tidak terlepas dari masyarakat dan lingkungan. Perkembangan perusahaan seharusnya sejalan dengan perkembangan masyarakat dan daerah sekitar perusahaan. Konsep pengembangan masyarakat dicerminkan dalam pemberdayaan masyarakat yang merupakan salah satu kunci sukses dalam menjalankan pembangunan suatu daerah.

Bentuk pemberdayaan masyarakat dari perusahaan adalah Tanggung Jawab Sosial (TJS) perusahaan yang merupakan konsekuensi logis hukum sebab-akibat, di mana ketika operasional perusahaan memberikan dampak bagi masyarakat. Dengan adanya program TJS perusahaan menjadi salah satu ukuran kepedulian perusahaan terhadap masyarakat sekitar perusahaan yang selanjutnya menjadi aspek penting dalam keberdayaan masyarakat.

Tanggung jawab sosial perusahaan mutlak diperlukan, baik untuk kepentingan pihak luar perusahaan yaitu pemerintah daerah dan masyarakat juga bagi kepentingan perusahaan itu sendiri. Jika dikaitkan dengan keuntungan perusahaan, disadari bahwa keuntungan itu diperoleh (1) Berkat usaha dari seluruh karyawan perusahaan mulai level bawah hingga tertinggi, (2) Pengorbanan masyarakat sekitar dengan mengorbankan sumber daya alam milik mereka, serta dampak yang ditimbulkan oleh perusahaan 
terhadap potensi ekonomi mereka, (3) Pemerintah dengan kewenangan kebijakan yang memberikan fasilitasfasilitas kepada perusahaan untuk melegalisasi kegiatan produksi perusahaan. Terkait usaha dan pengorbanan ketiga pihak itu, selayaknya perusahaan dalam kegiatan operasionalnya juga mempunyai tanggung jawab sosial kepada ketiga pihak di atas, dan tidak hanya semata membayar pajak (Zainal 2006).

Bentuk implementasi program TJS perusahaan memiliki karakteristik yang berbeda setiap perusahaan. Beberapa program TJS perusahaan diimplementasikan dalam kegiatan community relations (hubungan komunitas). Community relations merupakan bentuk TJS perusahaan. Wajar bila berbagai perusahaan di Indonesia kini sudah menjalankan tanggung jawab sosialnya itu dalam bentuk program dan kegiatan community relations. Keberhasilan suatu perusahaan salah satunya ditentukan oleh adanya perhatian terhadap lingkungan sosial sekitar. Artinya, sukses komersial perusahaan-perusahaan dilihat juga dari bagaimana perusahaan mengelola tanggung jawab sosial terhadap komunitas. Pertimbangan tersebut perlu diperhatikan, mengingat tidak sedikit permasalahan perusahaan timbul akibat hubungan di antara keduanya tidak harmonis, konflik berkepanjangan sering terjadi, dan tindakan anarkis masyarakat sekitar sering terdengar, hanya dikarenakan upaya pihak perusahaan dalam masalah TJS perusahaan tidak ditangani secara serius (Yulianita 2008).

Di Indonesia, pelaksanaan program TJS perusahaan diatur dalam UU Nomor 40/2007, selain itu diatur juga dalam UU Nomor 25/2007 tentang Penanaman Modal, Peraturan Pemerintah Nomor 47 Tahun 2012 tentang Tanggung Jawab Sosial dan Lingkungan. Di Kabupaten Bogor, diperkuat lagi dengan Peraturan Daerah Nomor 6 Tahun 2013 tentang Tanggung Jawab Sosial dan Lingkungan Perusahaan.

Desa Lulut merupakan salah satu desa yang termasuk wilayah administratif Kabupaten Bogor sekaligus salah satu desa binaan TJS perusahaan karena letaknya yang bersentuhan langsung dengan kegiatan penambangan. TJS yang diterapkan di Desa Lulut adalah program reklamasi lahan bekas tambang. Perusahaan melalui program TJS perusahaan, diharapkan mampu memahami permasalahan yang terdapat masyarakat, dengan memberikan solusi bagi masyarakat untuk mengembangkan potensi-potensi yang ada sebagai wadah untuk memberdayakan masyarakat sekaligus menyampaikan tujuan perusahaan sehingga pada akhirnya akan menciptakan pemahaman bagi para pemangku kepentingan (stakeholders).

Berdasarkan pemaparan latar belakang di atas, maka fokus penelitian ini adalah pentingnya pengukuran pendekatan komunikasi melalui kegiatan pemberdayaan program TJS perusahaan terhadap masyarakat di desa. Beberapa pertanyaan penelitian dirumuskan sebagai berikut: (1) Bagaimana persepsi penerima manfaat terhadap penerapan saluran komunikasi dan pendekatan komunikasi yang dilakukan dalam program TJS perusahaan? (2) Faktor apa yang membentuk Karakteristik penerima manfaat? (3) Bagaimana pengaruh karakteristik penerima manfaat, saluran komunikasi dan pendekatan komunikasi program TJS perusahaan terhadap keberdayaan masyarakat?

Berdasarkan perumusan masalah tersebut, secara umum penelitian bertujuan untuk mendapatkan informasi dan kejelasan mengenai bentuk pendekatan komunikasi program TJS perusahaan untuk keberdayaan masyarakat. Tujuan penelitian secara khusus adalah untuk: (1) Mengetahui persepsi penerapan saluran komunikasi dan pendekatan komunikasi yang dilakukan dalam program TJS perusahaan. (2) Mengetahui faktor-faktor yang membentuk karakteristik penerima manfaat. (3) Menganalisis pengaruh karakteristik penerima manfaat, saluran komunikasi dan pendekatan komunikasi program TJS perusahaan terhadap keberdayaan masyarakat.

\section{METODE}

Penelitian dilakukan di Kabupaten Bogor dengan mengambil lokasi di Desa Lulut yang merupakan salah satu desa binaan TJS perusahaan. Sampel penelitian ini dilakukan secara purposive yaitu kepada 74 orang penerima manfaat dari kegiatan TJS. Penelitian ini didesain menggunakan mix method yakni pendekatan penelitian yang mengkombinasikan atau mengasosiasikan bentuk kualitatif dan kuantitatif (Creswell, 2009). Riset ini juga mengkombinasikan antara penelitian menerangkan (explanatory research) dengan penelitian deskriptif (descriptive research) dan pengujian dari hipotesis. Metode penelitian ini menggunakan Focus Group Discussion (FGD) dan metode survei dengan pendekatan multi analisis yaitu analisis deskriptif untuk melihat persepsi responden terhadap variabel penelitian dan structural equation model (SEM) untuk mengetahui pengaruh antar variabel.

\section{HASIL DAN PEMBAHASAN}

\section{Persepsi Saluran Komunikasi Program TJS Perusahaan}

Saluran komunikasi merupakan alat yang digunakan sumber pesan dalam menyampaikan pesan kepada penerima. Saluran ini dianggap sebagai sarana dalam menyampaikan informasi program TJS perusahaan kepada masyarakat. Adapun indikator-indikator peubah saluran komunikasi dalam penelitian ini antara lain kebijakan korporasi, peran pendamping, peran tokoh masyarakat dan peran media.

Dari Tabel 2 terlihat sebaran frekuensi dan persentase persepsi penerima manfaat di Desa Lulut untuk indikator kebijakan korporasi dinilai kurang 
baik oleh penerima manfaat. Sebanyak 40 orang atau 54.1 persen dari 74 responden menilai kebijakan terkait program TJS perusahaan pada kategori buruk. Frekuensi penerima manfaat, sebanyak 30 orang atau 40.5 persen menilai penerapan kebijakan perusahaan terkait program TJS kategori baik. Masing-masing sisanya satu orang atau 1.5 persen penerima manfaat menilai kebijakan perusahan pada kategori sangat baik dan 3 orang atau 4.1 menilai pada kategori sangat buruk.

Masyarakat Desa Lulut sebagai penerima manfaat program TJS perusahaan mempersepsikan peran pendamping atau Kordes belum bekerja dengan baik dimana 50 orang atau 67.6 persen dari total 74 responden menilai peran Kordes pada kategori buruk. Sedangkan, 17 orang atau 23 persen menilai kinerja Kordes kategori baik. Masing-masing 2 orang atau 2.7 persen penerima manfaat Desa Lulut yang menilai peran Kordes pada kategori sangat baik dan ada 5 orang atau 6.8 persen penilaian pada kategori sangat buruk.

Pada indikator peran tokoh masyarakat atau tokoh informal di Desa Lulut dinilai penerima manfaat kurang berperan dengan maksimal dimana 42 orang atau 56.8 persen dari total 74 responden menilai peran tokoh masyarakat pada kategori buruk. Sebanyak 21 orang atau 28.4 persen peran tokoh masyarakat pada kategori baik. Sebanyak 9 orang atau 12.1 persen menilai peran tokoh masyarakat pada kategori sangat baik dan 2 orang atau 2.7 persen menilai pada kategori sangat buruk.

Pada indikator peran media di Desa Lulut dinilai penerima manfaat kurang dirasakan manfaatnya dimana 29 orang atau 39,2 persen dari total 74 responden menilai peran tokoh masyarakat pada kategori buruk dan sebanyak 45 orang atau 60.8 persen menilai pada kategori sangat buruk. Hal ini juga sesuai dengan pendapat Sari (2012) dimana kualitas Corporate Social Responsibility Disclosure tidak mudah untuk diukur, umumnya perusahaan melakukan Corporate Social Responsibility Disclosure hanya sebagai bagian dari iklan dan menghindari untuk memberikan informasi yang relevan. Dengan demikian peran media sebagai sumber informasi tidak menjadi bagian penting dalam implementasi program TJS perusahaan.

\section{Pendekatan Komunikasi Program TJS Perusahaan}

Bentuk TJS perusahaan yang terkait dengan pemberdayaan masyarakat terdiri program pengembangan masyarakat atau community development dan program pembangunan berkelanjutan atau sustainable development programs.

Data yang tersaji pada Tabel 3 menujukkan persepsi masyarakat di Desa Lulut sebagai penerima manfaat masyarakat terhadap pendekatan komunikasi program TJS perusahaan. Penerima manfaat di Desa Lulut melihat indikator community development cenderung pada posisi yang tidak menguntungkan. Hal ini terlihat dari sebanyak 25 orang atau 33.8 persen dari total 74 responden menilai pendekatan program TJS perusahaan dengan community development masuk kategori baik, sedangkan sebanyak 46 orang atau 62.1 persen menilai pendekatan community development kategori buruk. Sisanya, 1 orang atau 1.4 persen menilai pada kategori sangat baik dan 2 orang atau 2.7 menilai pada kategori sangat buruk.

Sementara pandangan masyarakat Desa Lulut sebagai penerima manfaat terhadap pendekatan sustainable development cenderung negatif. Artinya, penerima manfaat lebih cenderung menolak pendekatan sustainable development dimana sebanyak 48 orang

Tabel 2. Sebaran frekuensi, persentase dan rataan skor peubah saluran komunkasi

\begin{tabular}{|c|c|c|c|c|c|c|c|}
\hline \multirow{2}{*}{\multicolumn{2}{|c|}{ Peubah Saluran Komunikasi }} & \multicolumn{5}{|c|}{ Jawaban } & \multirow{2}{*}{ Rataan Skor* } \\
\hline & & \multirow{2}{*}{$\begin{array}{c}\text { Sangat Baik } \\
1\end{array}$} & \multirow{2}{*}{$\begin{array}{c}\text { Baik } \\
30\end{array}$} & \multirow{2}{*}{$\begin{array}{c}\text { Buruk } \\
40\end{array}$} & \multirow{2}{*}{$\frac{\text { Sangat Buruk }}{3}$} & \multirow{2}{*}{$\begin{array}{c}\text { Total } \\
74\end{array}$} & \\
\hline Kehiigkan Kornoraci & $(f)$ & & & & & & 2.42 \\
\hline Kebıjakan Korporası & $(\%)$ & 1.3 & 40.5 & 54.1 & 4.1 & 100 & (Baik) \\
\hline \multirow{2}{*}{ Peran Pendamping } & $(f)$ & 2 & 17 & 50 & 5 & 74 & 2.3 \\
\hline & $(\%)$ & 2.7 & 23 & 67.6 & 6.8 & 100 & (Baik) \\
\hline \multirow{2}{*}{ Tokoh Maasyarakat } & $(f)$ & 9 & 21 & 42 & 2 & 74 & 2.53 \\
\hline & $(\%)$ & 12.1 & 28.4 & 56.8 & 2.7 & 100 & (Baik) \\
\hline \multirow{2}{*}{ Peran Media } & $(f)$ & 0 & 0 & 29 & 45 & 74 & 1.89 \\
\hline & $(\%)$ & 0 & 0 & 39.2 & 60.8 & 100 & (Buruk) \\
\hline
\end{tabular}

* Ket: 1 - 1.75: Sangat Buruk; 1.76 - 2.51: Buruk; 2.52 - 3.27: Baik; 3.28 - 4: Sangat Baik Hasil Olahan 2015

Tabel 3. Sebaran frekuensi, persentase dan rataan skor peubah pendekatan komunkasi

\begin{tabular}{ccccccccc}
\hline \multirow{2}{*}{ Peubah Pedekatan Komunikasi } & \multicolumn{3}{c}{ Jawaban } & & \multicolumn{2}{c}{$\begin{array}{c}\text { Rataan } \\
\text { Skor* }\end{array}$} \\
\cline { 3 - 7 } & & Sangat Baik & Baik & Buruk & Sangat Buruk & Total & 2.4 \\
Community & $(f)$ & 1 & 25 & 46 & 2 & 74 & 100 & (Buruk) \\
Development & $(\%)$ & 1.4 & 33.8 & 62.1 & 2.7 & 6 & 74 & $\mathbf{2 . 3 4}$ \\
Sustainable & $(f)$ & 4 & 16 & 48 & 8.1 & 100 & (Buruk) \\
Development & $(\%)$ & 5.4 & 21.6 & 64.9 &
\end{tabular}


atau 64.9 persen responden menilai pada kategori buruk dan 17 orang atau 21.6 persen menilai pendekatan ini pada kategori baik. Sisanya, 4 orang atau 5.4 persen menilai pada kategori sangat baik dan 6 orang atau 8.1 menilai pada kategori sangat buruk. Secara umum, berdasarkan rataan skor pada Tabel $\mathrm{x}$ di atas terlihat kedua pendekatan komunikasi tersebut dikategorikan baik dan tidak terdapat ketimpangan skor yang mencolok antara satu pendekatan dengan yang lain dimana skor untuk pendekatan community development sebesar 2.4 dan untuk pendekatan sustainable development sebesar 2.34 .

\section{Keberdayaan Masyarakat}

Keberadaan TJS perusahaan memiliki landasan yang kuat sejak John Eklington melalui karya tulisnya Cannibals with Forks, the Triple Bottom Line of Twentieth Century Business yang memperkenalkan konsep triple bottom line. Konsep ini menganut pandangan bahwa perusahaan yang ingin berkelanjutan (sustainable) haruslah memperhatikan 3P, yakni: profit (keuntungan), people (masyarakat pemangku kepentingan) dan planet (lingkungan). Menurut pandangan ini, perusahaan selain mengejar keuntungan (profit), juga mesti memperhatikan dan terlibat dalam pemenuhan kesejahteraan masyarakat (people) dan turut berkontribusi aktif dalam menjaga kelestarian lingkungan (Wibisono 2007). Pandangan ini bermuara pada kemampuan dan usaha perusahaan untuk menciptakan keberdayaan masyarakat.

Hasbullah (2012) menyatakan bahwa peran TJS perusahaan PKT dalam pemberdayaan ekonomi masyarakat di kawasan pesisir cenderung masih lemah dan bersifat sporadis, hal ini terlihat dari kinerja sebagian besar program TJS perusahaan PKT yang dinilai belum cukup memenuhi harapan masyarakat dan kurang berfokus pada upaya pengelolaan kawasan pesisir terpadu. Birth et.al. (2008) memberikan gambaran bahwa komunikasi TJS perusahaan di Swiss berkembang dengan baik, meskipun masih memiliki batas-batas untuk pembangunan.

Merujuk data pada Tabel 4 sebaran frekuensi dan persentase persepsi penerima manfaat di Desa Lulut untuk indikator keberdayaan sektor ekonomi dinilai buruk oleh penerima manfaat. Sebanyak 21 orang atau 28.9 persen dari 74 responden menilai keberdayaan sektor ekonomi dari implementasi program TJS perusahaan pada kategori baik. Frekuensi penerima manfaat, sebanyak 38 orang atau 51.4 persen menilai keberdayaan aspek ekonomi terkait program TJS kategori buruk. Masing-masing sisanya 1 orang atau 1.4 persen penerima manfaat menilai kebijakan perusahan pada kategori sangat baik dan 14 orang atau 18.9 menilai pada kategori sangat buruk.

Sektor lain yaitu pendidikan masyarakat Desa Lulut sebagai penerima manfaat program TJS perusahaan mempersepsikan keberdayaan pendidikan juga dirasakan belum maksimal dimana hanya 4 orang atau 5.4 persen dari total 74 responden menilai keberdayaan sektor pendidikan pada kategori sangat baik dan 27 orang atau 36.5 persen menilai pada kategori baik. Sedangkan, 39 orang atau 52.7 persen menilai sektor pendidikan belum maksimal atau pada kategori buruk dan 4 orang atau 5.4 persen penerima manfaat Desa Lulut menilai pada kategori sangat buruk.

Sektor keberdayaan pada aspek kesehatan, Tabel 4 menunjukan penerima manfaat program TJS perusahaan di Desa Lulut menilai aspek kesehatan sudah cukup baik. Sebanyak 30 orang atau 40.5 persen dari total 74 responden menilai masyarakat telah memperoleh manfaat dari program TJS perusahaan dan dikategorikan pada kategori baik. Namun, sebanyak 34 orang atau 46 persen dinilai pada kategori buruk. Sebanyak 9 orang atau 12.2 persen menilai pada kategori sangat baik dan 1 orang atau 1.4 persen menilai pada kategori sangat buruk.

Penilaian penerima manfaat program TJS di Desa Lulut pada aspek sosial-infrastruktur cenderung negatif. Berdasarkan Tabel 4, diketahui penerima manfaat di Desa Lulut menilai keberdayaan pada aspek ini kurang mempunyai nilai manfaat dimana dari total 74 responden sebanyak 43 orang atau 58.1 persen menilai keberdayaan sosial-infrastruktur pada kategori sangat buruk dan 3 orang atau 4.1 persen menilai pada kategori sangat buruk. Sementara, hanya 2 orang atau 2.7 persen yang menilai pada kategori sangat baik dan 26 orang atau 35.1 persen menilai pada kategori baik.

Tabel 4. Sebaran frekuensi, persentase dan rataan skor peubah keberdayaan masyarakat

\begin{tabular}{|c|c|c|c|c|c|c|c|}
\hline \multirow{2}{*}{\multicolumn{2}{|c|}{$\begin{array}{c}\text { Peubah Keberdayaan } \\
\text { Masyarakat }\end{array}$}} & \multicolumn{5}{|c|}{ Jawaban } & \multirow{2}{*}{ Rataan Skor* } \\
\hline & & \multirow{2}{*}{$\frac{\text { Sangat Baik }}{1}$} & \multirow{2}{*}{$\frac{\text { Baik }}{21}$} & \multirow{2}{*}{$\frac{\text { Buruk }}{38}$} & \multirow{2}{*}{$\frac{\text { Sangat Buruk }}{14}$} & \multirow{2}{*}{$\frac{\text { Total }}{74}$} & \\
\hline Fly & $(f)$ & & & & & & 2.28 \\
\hline ЕконОП & $(\%)$ & 1.4 & 28.9 & 51.4 & 18.9 & 100 & (Buruk) \\
\hline \multirow{2}{*}{ Pendidikan } & $(f)$ & 4 & 27 & 39 & 4 & 74 & 2.41 \\
\hline & $(\%)$ & 5.4 & 36.5 & 52.7 & 5.4 & 100 & (Buruk) \\
\hline \multirow{2}{*}{ Kesehatan } & $(f)$ & 9 & 30 & 34 & 1 & 74 & 2.62 \\
\hline & $(\%)$ & 12.2 & 40.5 & 46 & 1.4 & 100 & (Baik) \\
\hline Sosial & $(f)$ & 2 & 26 & 43 & 3 & 74 & 2.39 \\
\hline Infrastruktur & $(\%)$ & 2.7 & 35.1 & 58.1 & 4.1 & 100 & (Buruk) \\
\hline \multirow{2}{*}{ Keamanan } & $(f)$ & 8 & 17 & 29 & 20 & 74 & 2.2 \\
\hline & $(\%)$ & 10.8 & 23 & 39.2 & 27 & 100 & (Buruk) \\
\hline
\end{tabular}

* Ket: 1-1.75: Sangat Buruk; 1.76 - 2.51: Buruk; 2.52 - 3.27: Baik; 3.28 - 4: Sangat Baik Hasil Olahan 2015 
Penilaian pada aspek keamanan juga cenderung negatif. Penerima manfaat di Desa Lulut menilai keberdayaan pada aspek ini kurang mempunyai nilai manfaat dimana dari total 74 responden sebanyak 29 orang atau 39.2 persen menilai pada kategori sangat buruk dan 20 orang atau 27 persen menilai pada kategori sangat buruk. Sementara, hanya 8 orang atau 10.8 persen yang menilai pada kategori sangat baik dan 17 orang atau 23 persen menilai pada kategori baik.

Berdasarkan rataan skor hasil penelitian secara keseluruhan semua indikator keberdayaan masyarakat di Desa Lulut hanya keberdayaan pada aspek kesehatan yang dikategorikan baik yakni dengan rataan skor 2.62. Sementara, empat indikator lainnya yakni keberdayaan ekonomi, pendidikan, sosial-insfrastruktur dan keamanan dikategorikan buruk. Dapat dikatakan masyarakat Desa Lulut belum merasakan manfaat atas implementasi program TJS perusahaan secara maksimal khususnya untuk empat pilar yang dinilai

\section{Faktor-faktor Yang Mempengaruhi Karakteristik Penerima Manfaat}

Dalam melaksanakan kegiatan/program CSR, perusahaan selaku pihak perencana dan pelaksana program seyogyanya mempertimbangkan karakteristik masyarakat sasaran CSR. Karakteristik masyarakat dapat menunjukkan arah untuk dapat mengidentifikasi kebutuhan dan keinginan masyarakat (Gani dkk, 2015). Data karakteristik penerima manfaat program TJS perusahaan meliputi beberapa indikator yaitu tingkat pendidikan, pekerjaan, pendapatan, status sosial, partisipasi sosial, dan keterdedahan media.

Berdasarkan hasil pengolahan, diketahui bahwa pada Desa Lulut faktor yang berpengaruh dalam membentuk karakteristik penerima manfaat adalah pendidikan, dan status sosial, hal ini ditunjukan dengan nilai signifikan ditentukan dari nilai t statistik lebih dari 1.96 atau $p$ value $<0.05$. Lebih jelas mengenai signifikansi bobot tiap indikator dapat dilihat pada Tabel 5 .

Tabel 5. Signifikansi bobot indikator peubah penerima manfaat

\begin{tabular}{lcl}
\hline \multicolumn{1}{c}{ Indikator } & Signifikansi & \multicolumn{1}{c}{ Keterangan } \\
\hline Pendidikan & $2.689 *$ & Berpengaruh \\
Pekerjaan & 0.539 & Tidak Berpengaruh \\
$\begin{array}{l}\text { Pendapatan } \\
\text { Status sosial }\end{array}$ & 1.241 & Tidak Berpengaruh \\
$\begin{array}{l}\text { Partisipasi } \\
\text { (Frekuensi) }\end{array}$ & $3.804 *$ & Berpengaruh \\
$\begin{array}{l}\text { Partisipasi (intensitas) } \\
\begin{array}{l}\text { Keterdedahan } \\
\text { (intensitas) }\end{array}\end{array}$ & 1.045 & Tidak Berpengaruh \\
$\begin{array}{l}\text { Keterdedahan (jumlah } \\
\text { media) }\end{array}$ & 0.990 & Tidak Berpengaruh \\
\hline & 0.889 & Tidak Berpengaruh \\
\hline
\end{tabular}

\section{Model Komunikasi Tanggung Jawab Sosial Keberdayaan Masyarakat Sekitar}

Keberdayaan masyarakat merupakan langkah dan agenda yang penting bagi pelaksanaan dan implementasi program TJS perusahaan yang terdiri dari lima pilar keberdayaan. Kelimapilartersebutantara lain adalahaspek ekonomi, pendidikan, kesehatan, sosial-insfrasruktur dan keamanan. Lima pilar keberdayaan masyarakaat dalam program TJS perusahaan tersebut tidak dapat berdiri sendiri. Masing-masing pilar tergantung dan dipengaruhi oleh beberapa faktor penting.

Dalam penelitian ini, keberdayaan masyarakat terkait program TJS perusahaan dipengaruhi oleh berbagai faktor seperti karakteristik penerima manfaat, saluran komunikasi dan pendekatan komunikasi. Pengujian peubah yang memiliki pengaruh dalam penelitian ini menggunakan Structural Equation Model Partial Least Square (SEM PLS) dengan software SmartPLS version 2.0. Terdapat tiga peubah laten dalam penelitian yakni karakteristik penerima manfaat, saluran komunikasi dan pendekatan komunikasi. Setiap peubah laten memiliki masing-masing peubah manifest (indikator) sesuai dengan yang dijabarkan pada metode penelitian.

Penggunaan PLS dapat mengukur suatu hubungan yang tidak bisa diukur secara langsung. Selain itu, PLS juga memperbolehkan indikator formatif dalam mengukur peubah laten selain indikator reflektif. Hal ini tidak diijinkan dalam SEM berbasis kovarian yang menggunakan indikator reflektif saja. Oleh karena itu pemilihan PLS sebagai alat analisis dirasa tepat karena mampu menjelaskan hubungan yang kompleks dalam penelitian ini antara karakteristik penerima manfaat, saluran komunikasi, pendekatan komunikasi dan keberdayaan masyarakat. Untuk mengevaluasi model dalam penelitian ini diperlukan beberapa cara bergantung pada model yang telah dibentuk. Secara umum evaluasi dan interpretasi model dapat dilihat sebagai berikut.

\section{Estimasi Koefisien Jalur}

Hasil bootstraping yang terdapat pada Tabel 6 menunjukkan koefisien untuk tiap jalur hipotesis dan nilai T-Statistiknya yang diperoleh dari hasil output SmartPLS.

Pada Tabel 6, diketahui bahwa pada model Desa Lulut terdapat pengaruh nyata dari karakteristik penerima manfaat terhadap saluran komunikasi, selain itu konstruk pendekatan komunikasi program TJS dan saluran komunikasi terhadap keberdayaan masyarakat, serta saluran komunikasi terhadap pendekatan komunikasi dengan nilai $p$-value $<0,05$ atau nilai t-hitung $>\mathrm{t}$-tabel $(1,96)$.

Jika dilihat dari efek total terhadap variabel eksogen, diketahui bahwa variabel keberdayaan masyarakat dipengaruhi secara berurutan oleh variabel saluran komunikasi (0,790), variabel pendekatan komunikasi $(0,606)$ dan karakteristik penerima manfaat $(0,352)$. Lebih jelas mengenai efek total variabel dapat dilihat pada Tabel 7 . 
Tabel 6. Hasil Bootstrap Bobot Tiap peubah eksogen terhadap peubah endogen

\begin{tabular}{|c|c|c|c|c|c|}
\hline & $\begin{array}{c}\text { Original } \\
\text { Sample (O) }\end{array}$ & $\begin{array}{c}\text { Sample } \\
\text { Mean (M) }\end{array}$ & $\begin{array}{l}\text { Standard } \\
\text { Deviation } \\
\text { (STDEV) }\end{array}$ & $\begin{array}{l}\text { T Statistics }(\mid \mathbf{O} / \\
\text { STDEV } \mid)\end{array}$ & P Values \\
\hline $\begin{array}{l}\text { Pendekatan Komunikasi } \rightarrow \text { Keberdayaan } \\
\text { Masyarakat }\end{array}$ & 0.606 & 0.608 & 0.095 & 6.416 & 0.000 \\
\hline $\begin{array}{l}\text { Profil Penerima Manfaat } \rightarrow \text { Keberdayaan } \\
\text { Masyarakat }\end{array}$ & -0.115 & -0.076 & 0.089 & 1.298 & 0.195 \\
\hline $\begin{array}{l}\text { Profil Penerima Manfaat } \rightarrow \text { Pendekatan } \\
\text { Komunikasi }\end{array}$ & 0.064 & 0.111 & 0.117 & 0.545 & 0.586 \\
\hline $\begin{array}{l}\text { Profil Penerima } \\
\text { Komunikasi }\end{array}$ & 0.542 & 0.583 & 0.099 & 5.476 & 0.000 \\
\hline $\begin{array}{l}\text { Saluran Komunikasi } \rightarrow \text { Keberdayaan } \\
\text { Masyarakat }\end{array}$ & 0.344 & 0.326 & 0.102 & 3.375 & 0.001 \\
\hline $\begin{array}{l}\text { Saluran Komunikasi } \rightarrow \text { Pendekatan } \\
\text { Komunikasi }\end{array}$ & 0.735 & 0.709 & 0.081 & 9.132 & 0.000 \\
\hline
\end{tabular}

Tabel 7. Efek total peubah eksogen

\begin{tabular}{|c|c|c|c|c|}
\hline Peubah & $\begin{array}{c}\text { Keberdayaan } \\
\text { Masyarakat }\end{array}$ & $\begin{array}{l}\text { Pendekatan } \\
\text { Komunikasi }\end{array}$ & $\begin{array}{c}\text { Profil } \\
\text { Penerima } \\
\text { Manfaat }\end{array}$ & $\begin{array}{c}\text { Saluran } \\
\text { Komunikasi }\end{array}$ \\
\hline Keberdayaan Masyarakat & 1.000 & & & \\
\hline Pendekatan Komunikasi & 0.606 & 1.000 & & \\
\hline Profil Penerima Manfaat & 0.352 & 0.462 & 1.000 & 0.542 \\
\hline Saluran Komunikasi & 0.790 & 0.735 & & 1.000 \\
\hline
\end{tabular}

\section{R-square}

Kekuatan untuk menjelaskan (explanatory power) yang dimiliki model, atau validitas nomologis (nomological validity), dapat dinilai dengan melihat $\mathrm{R}$-square $\left(\mathrm{R}^{2}\right)$ dari konstruk-konstruk endogen atau peubah dependen yakni: karakteristik penerima manfaat, saluran komunikasi dan pendekatan komunikasi. Nilai R-Square digunakan untuk menilai pengaruh peubah laten independen tertentu terhadap peubah laten dependen, apakah mempunyai pengaruh yang substantif. Tabel 8 menunjukkan R-Square untuk peubah dependen.

Tabel 8. Nilai R-Square peubah laten

\begin{tabular}{lc}
\hline \multicolumn{1}{c}{ Peubah } & R Square \\
\hline Keberdayaan Masyarakat & 0.713 \\
Pendekatan Komunikasi Program TJS & 0.595 \\
Saluran Komunikasi & 0.294 \\
\hline
\end{tabular}

Hasil Olahan 2015

Dari Tabel 8, diketahui bahwa nilai $\mathrm{R}^{2}$ untuk variabel pendekatan komunikasi sebesar 0,595 (termasuk pada penggolongan baik/ substansial), hal ini menunjukan bahwa variabilitas pendekatan komunikasi dapat dijelaskan oleh konstruk karakteristik penerima manfaat dan saluran komunikasi sebesar 59,5\%. Pada variabel saluran komunikasi dapat dijelaskan oleh variabel karakteristik penerima manfaat sebesar 0,294 atau sebesar 29,4\%. Variabel keberdayaan masyarakat diketahui memiliki nilai $\mathrm{R}^{2}$ sebesar 0,713 (termasuk pada penggolongan baik/subtansial), hal tersebut menunjukan bahwa variabilitas keberdayaan masyarakat dapat dijelaskan oleh variabel karakteristik penerima manfaat, saluran komunikasi dan pendekatan komunikasi program TJS sebesar 71,3\% sedangkan $28,7 \%$ dijelaskan oleh variabel lain diluar penelitian.

\section{Pengujian Hipotesis}

Berdasarkan analisa model penelitian ini dengan menggunakan PLS, diperoleh model penelitian yang disajikan pada Gambar 1 dan t-hitung model penelitian akhir yang disajikan pada Gambar 2 .

Berdasarkan hasil pengolahan dan pembahasan sebelumnya, diketahui bahwa dari enam hipotesis khusus penelitian, didapatkan dua dari enam tidak memenuhi syarat sehingga hipotesis ditolak. Adapun hipotesis yang ditolak adalah pengaruh karakteristik penerima manfaat terhadap keberdayaan masyarakat dan pengaruh peubah karakteristik penerima manfaat terhadap pendekatan komunikasi program TJS. Sedangkan hipotesis yang diterima meliputi: pengaruh Karakteristik Penerima Manfaat terhadap saluran komunikasi, pengaruh pendekatan komunikasi program TJS terhadap keberdayaan masyarakat, pengaruh saluran komunikasi terhadap keberdayaan masyarakat, pengaruh saluran komunikasi terhadap pendekatan komunikasi program TJS.

Merujuk pada Tabel 6, terlihat hipotesis penelitian yang menyatakan bahwa karakteristik/profil penerima manfaat tidak berpengaruh terhadap pendekatan komunikasi dan keberdayaan masyarakat, namun berpengaruh 


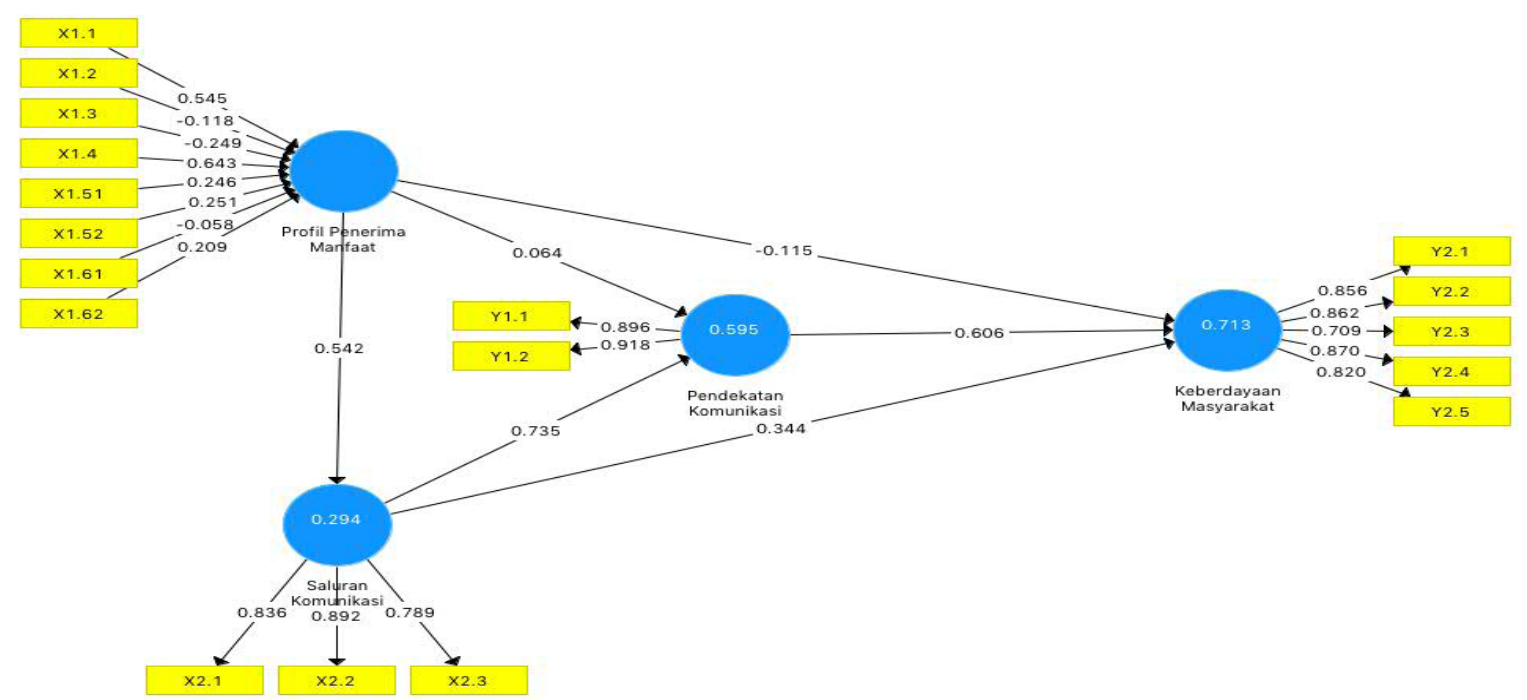

Gambar 1. Hasil Perhitungan Model Komunikasi Pada Desa Lulut

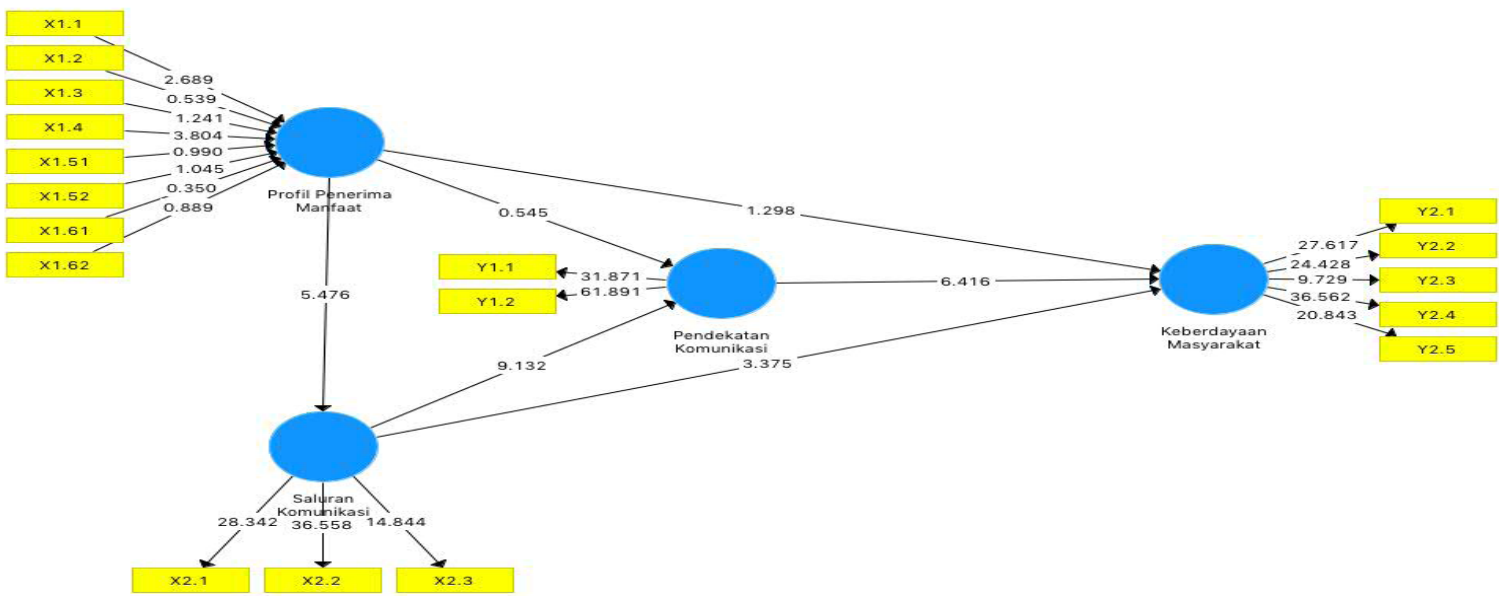

Gambar 2. Hasil Perhitungan t-hitung Model Komunikasi Pada Desa Lulut

signifikan terhadap saluran komunikasi yang ditunjukan dengan nilai (original sample estimate 0.542, t-hitung 5.476). Besarnya koefisien antara peubah karakteristik penerima manfaat terhadap saluran komunikasi sebesar 0,321, yang dalam hal ini termasuk dalam kategori moderat atau sedang. Dengan kata lain, apabila karakteristik penerima manfaat meningkat yang meliputi pendidikan, pendapatan, status sosial dan partisipasi sosial maka akan meningkatkan pemahaman terhadap saluran komunikasi. Dengan demikian hipotesis penelitian $\left(\mathrm{H}_{1}\right)$ yang menyebutkan terdapat pengaruh nyata antara karakteristik penerima manfaat berpengaruh terhadap saluran komunikasi diterima pada kategori moderat atau sedang.

Peubah saluran komunikasi terhadap pendekatan komunikasi didapatkan pengaruh signifikan (original sample estimate 0.735, t-hitung 9.132) Besarnya koefisien antara peubah saluran komunikasi terhadap pendekatan komunikasi sebesar 0.735 dalam hal ini termasuk subtansial. Dengan demikian hipotesis penelitian $\left(\mathrm{H}_{1}\right)$ yang menyebutkan terdapat hubungan nyata antara saluran komunikasi terhadap pendekatan komunikasi program TJS perusahaan diterima.

Peubah saluran komunikasi terhadap keberdayaan masyarakat didapatkan pengaruh signifikan (original sample estimate 0.344, t-hitung 3.375) Besarnya koefisien antara peubah saluran komunikasi terhadap keberdayaan masyarakat sebesar 0.344 dalam hal ini termasuk korelasi moderat. Dengan demikian hipotesis penelitian $\left(\mathrm{H}_{1}\right)$ yang menyebutkan terdapat hubungan nyata antara saluran komunikasi terhadap keberdayaan masyarakat diterima.

Peubah pendekatan komunikasi terhadap keberdayaan masyarakat didapatkan pengaruh signifikan (original sample estimate 0.606, t-hitung 6.416). Besarnya koefisien antara peubah pendekatan komunikasi terhadap keberdayaan masyarakat sebesar 0.606 dalam hal ini termasuk korelasi moderat. Oleh karena itu, hipotesis penelitian $\left(\mathrm{H}_{1}\right)$ yang menyebutkan terdapat hubungan nyata antara pendekatan komunikasi program TJS perusahaan terhadap keberdayaan masyarakat diterima. Dengan demikian, pendekatan komunikasi 
dalam program TJS perusahaan baik dalam pendekatan CD maupun SD berpengaruh terhadap keberdayaan masyarakat.

\section{SIMPULAN}

Persepsi responden terhadap saluran komunikasi, secara umum dinilai baik untuk peubah kebijakan korporasi, peran pendamping dan peran tokoh masyarakat, sedangkan peran media masih dinilai buruk dengan nilai rataan sebesar 1.84. Persepsi penerima manfaat terhadap peubah pendekatan komunikasi, secara umum dinilai buruk dengan nilai rataan sebesar 2.4 untuk community development dan 2.34 untuk sustainable development. Untuk peubah keberdayaan masyarakat, secara umum penerima manfaat menilai buruk dengan nilai rataan 2.28 untuk keberdayaan ekonomi, 2.41 untuk keberdayaan pendidikan, 2.39 untuk keberdayaan sosial infrastruktur dan 2.2 untuk keberdayaan keamanan. Hanya keberdayaan kesehatan yang dinilai baik dengan rataan sebesar 2.98.

Karaktersitik penerima manfaat yang menjadi pengaruh adalah pendidikan dan status social.

Dari tiga peubah yang mempengaruhi keberdayaan masyarakat, diketahui hanya pendekatan komunikasi dan saluran komunikasi yang berpengaruh langsung signifikan terhadap keberdayaan masyarakat, sedangkan karakteristik penerima manfaat berpengaruh signifikan terhadap saluran komunikasi.

Berdasarkan simpulan tersebut disarankan kepada perusahaan dan instansi terkait untuk mengoptimalkan pemilihan penerima manfaat pada indikator pendidikan dan status sosial Karena sebagai determinan yang berpengaruh pada peubah saluran komunikasi dan pendekatan komunikasi karena berpengaruh signifikan kepada keberdayaan masyarakat dengan berfokus pada kebedayaan ekonomi, pendidikan, social infrastruktur dan keamanan karena masih dinilai kurang baik/buruk oleh penerima manfaat.

\section{DAFTAR PUSTAKA}

Birth, G., Illia, L., Lurati, F. and Zamparini, A. (2008). Communicating CSR: Practices among Switzerland's top 300 companies. Corporate Communications: An International Journal, 13(2): 182-190
Creswell, J. (2009). Research Design Pendekatan Kualitatif, Kuantitatif, dan Mixed. Yogyakarta: Pustaka Pelajar

Gani I, Muliati, dan Amalia S. (2015). Pemetaan masyarakat sebagai target group program CSR PT. PKT Bontang. Jurnal Sosiohumaniora, Vol. 17 No 1 hal.28-34.

Hasbullah, T. (2012). Desain strategi tanggung jawab sosial perusahaan dalam pemberdayaan ekonomi masyarakat dan sumber daya pesisir Kota Bontang (Studi Kasus PT. Pupuk Kaltim) [disertasi]. Bogor (ID): Sekolah Pascasarjana Institut Pertanian Bogor.

Nugroho, D.R., Hubeis AVS, Saleh A, and Priatna W.B. (2016). Communication model of corporate social responsibility program for community empowerment. International journal of research in social science vol.6 no.6 pp 1-10Payne M. 1997. Modern Social Work Theory. Second Ed. London (GB): MacMillan Press Ltd.

[Sekneg RI] Sekretariat Negara Republik Indonesia. 2012. Peraturan Pemerintah Republik Indonesia tentang Tanggung Jawab Sosial dan Lingkungan Perseroan Terbatas. Jakarta (ID): Sekneg RI.

Sari, R.A. (2012). Pengaruh Karakteristik Perusahaan terhadap corporate social responsibility disclosure pada perusahaan manufaktur yang terdaftar di Bursa Efek Indonesia. Jurnal Nominal Vol 1 No.1 hal 124 - 140 Tahun 2012

Wibisono, Y. (2007). Membedah Konsep dan Aplikasi CSR (Corporate Social Responsibility). Gresik (ID): Fascho Publishing.

Yulianita, N. (2008). Corporate social responsibility (CSR) sebagai aktivitas sosial marketing public relations. Mediator, 9 (1): 123-133

Zainal, I.R. (2006. Best Practices: Corporate Social Responsibility, Sebuah Pengalaman Membangun Multistakeholder Engagment bagi Penerpan CSR di Kabupaten Muba Sumatera Selatan. Palembang (ID): Badan Penerbit Fakultas Ekonomi UNSRI. 